Araştırma Makalesi / Research Paper

\title{
Ilgın (Tamarix parviflora) Hemiselülozlarının Oktanoil, Dekanoil ve Lauroil Klorür ile Esterlenmesi
}

\author{
Samim YAŞAR \\ Süleyman Demirel Üniversitesi, Orman Fakültesi, Isparta \\ Geliş Tarihi (Received): 08.02.2018, Kabul Tarihi (Accepted): 19.03.2018 \\ $\square$ Sorumlu Yazar (Corresponding author): samimyasar@sdu.edu.tr \\ (C) +902462113973 圆 +902462113948
}

ÖZ

Bu çalışmada, endüstriyel anlamda hammadde olabilecek nitelikteki ılgın (Tamarix parviflora) bitkisinden izole edilen hemiselülozlardan oktanoil, dekanoil ve lauroil klorür kullanılarak üretilen esterler karakterize edilmiştir. Ilgın odunu ve hemiselülozlarının monosakkarit bileşimi HPLC ile belirlenmiştir. Çalışmada, elde edilen ester ürünlerin sübstitüsyon dereceleri 0,68 ile 0,81 ve yüzde verimleri 54,13 ile 58,23 aralığında yer almıştır. Örneklerin FTIR spektrumlarında elde edilen 3410, 2922, 2854 ve $1742 \mathrm{~cm}^{-1}$ 'deki band değerleri türevlendirmenin gerçekleştiğini göstermiştir. Doğal hemiselüloz örneğinin termal dayanıklıı̆ının ester ürünlerden daha yüksek olduğu TGA analizleri ile tespit edilmiştir. Sonuç olarak, hemiselüloz esterlerinde belirlenen karakteristik özellikler onların biyolojik ortamda ve çevresel şartlarda parçalanabilecek plastik, reçine ve film üretiminde kullanılabileceklerini göstermiştir.

Anahtar Kelimeler: Ilgın (Tamarix parviflora), hemiselülozların esterlenmesi, sübstitüsyon derecesi, yüzde verim

\section{Esterification of Small-flowered Tamarisk (Tamarix parviflora) Hemicellu- loses using Octanoyl, Decanoyl and Lauroyl chloride}

\begin{abstract}
In this study, the hemicelluloses were isolated from small-flowered tamarisk (Tamarix parviflora) which might be useful raw material in the industrial area, then esterified using octanoyl, decanoyl and lauroyl chloride. Afterwards, obtained hemicellulose esters were characterized. Monosaccharide composition of small-flowered tamarisk wood and hemicelluloses were determined by HPLC. The substitution degrees of esters were found between 0.68 and 0.81 and yield percentages between 54.13 and 58.23. The values of bands at 3410, 2922, 2854 and $1742 \mathrm{~cm}^{-1}$ in FTIR spectra of esters showed that the derivation of hemicelluloses occurred. Esters presented lower thermal stability compared to natural hemicelluloses after thermogravimetric analysis. The characteristic properties of produced hemicellulose esters indicated that these esters were found to be at a sufficient level for raw material in the production of biodegradable and environmentally degradable plastics, resins and films.
\end{abstract}

Keywords: Small-flowered tamarisk (Tamarix parviflora), esterification of hemicelluloses, degree of substitution, percentage of yield 


\section{Giriş}

Dünya nüfusunun hızlı artışı ve teknolojik gelişmeler orman ürünlerinin tüketimini artırmıştır. Dünyada kurutulmamış odun kullanımının yılda 3.5 milyar ton düzeyine ulaştığı ve kişi başına düşen odun miktarının 0.7 ton civarında olduğu belirtilmekte ve tüketimin gün geçtikçe artacağı öngörülmektedir. Orman kaynaklarında meydana gelen azalma zaman içerisinde artan talebin karşılanabilmesi için hammadde kaynaklarının planlı ve verimli bir şekilde kullanılmasının gerekliliğini göz önüne getirmiştir. Ayrıca, odun hammaddesinin günden güne çok değişik alanlarda kullanımının artması arz ve talep arasındaki dengesizliğin kaçınılmaz olacağını işaret etmektedir. Bu nedenle, odun esaslı hammaddelerin yanı sıra alternatif hammaddelerin kullanılması, geri dönüşümün etkili olarak uygulanması, daha etkin teknolojilerin kullanılması ve kalitesi yüksek yeni ürünlerin geliştirilmesi gelecekte odun arz ve talep dengesinin korunmasında önemli rol oynayacaktır (Cooper ve Balatinecz, 1999).

Ilgın (Tamarix parviflora) bitkisi, Batı Avrupa'dan Akdeniz çevresi boyunca ilerleyip Doğu Asya'ya kadar uzanan bölgede doğal yayılış göstermektedir. Ağaç veya çalı formunda göze çarpmaktadır. Dalları ince, uzun, kamçı görünüşlü olup, yaprakları yeşil veya mavimsi yeşil renklidir. Salkım şeklindeki göz alıcı çiçekleri pembe eflatun rengindedir. Ilgın kireçli, kumlu, çakıllı ve tuzlu toprakları tercih etmekte, bol güneşli ortamlarda ve akarsu kıyılarında sıkça görülmektedir (MEBMEGEP, 2007).

Petrol kökenli plastik malzemeler, üretimi esnasında ve kullanımından sonra atılması ile önemli derecede çevre kirliliğine neden olmaktadır. Plastik ambalaj malzemeleri, yaygın olarak kullanılmalarından ve doğal koşullarda uzun yıllar parçalanmaya dayanıklı oluşlarından dolayı her geçen gün kirliliğin artmasına sebep olmaktadır. Ayrıca, plastik malzemelerin geri dönüşümü ile elde edilmiş ürünlerin insan sağlığını tehdit ettiği bilinmekte$\operatorname{dir}$ (Önal, 2007).

Bitkisel kaynaklardan elde edilen hemiselülozların açil klorürler ile türevlendirilmesinden üretilen esterlerin lipofilik özellik sergilemesinden dolayı biyolojik ortamda ve çevresel şartlarda parçalanabilecek plastik, reçine ve film üretiminde kullanılabilecekleri belirtilmiştir (Sun ve ark., 2001).

Bu çalışmada, özellikle maki vejetasyonu içerisinde geniş bir yayılış alanına sahip, endüstriyel anlamda hammadde kaynağı olarak değerlendirilebilecek nitelikteki ılgından hemiselülozlar izole edildikten sonra oktanoil, dekanoil ve lauroil klorür ile esterlenerek hemiselüloz türevleri üretilmiştir. Ilgın odunu ve hemiselülozları- nın monosakkarit bileşimi yüksek performanslı sıvı kromatografisi (HPLC) ile saptanmıştır. Elde edilen ester ürünlerin karakterizasyonunda verim, sübstitüsyon derecesi (DS), fourier dönüşümlü kızılötesi (FTIR) spektroskopisi ve termogravimetrik analiz (TGA) kullanılmıştır.

\section{MATERYAL VE YÖNTEM}

\section{Materyal}

Isparta Aşağıgökdere yöresinden 2016 yılı eylül ayı içerisinde alınan ılgın örnekleri çalışma materyali olarak kullanılmıştır. Alınan gövde örnekleri kabukları soyulduktan sonra yongalanmış ve hava kurusu hale getirilmiştir. Daha sonra örnekler Retsch SK 1 değirmeninde 40-100 mesh aralığında öğütülmüştür.

\section{Yöntem}

Öğütülmüş örnek, soxhlet ekstraksiyon cihazında öncelikle 2:1 oranında siklohekzan:etanol karışımı ile 6 saat, devamında ise etanol ile işleme tabi tutulmuştur. Holoselüloz Wise ve Karl (1962)'a ait yöntem ile elde edilmiştir. $\alpha$-selüloz tayini ve hemiselüloz izolasyonu TAPPI T 203 os-71 ile gerçekleştirilmiştir.

İole edilen hemiselülozları içeren alkali ekstraktına $\mathrm{pH}$ derecesi 6 oluncaya kadar asetik asit ilave edilmiştir. Devamında ekstrakta hacminin 3 katı etanol ilave edilmiş ve hemiselülozların çökmesi sağlanmıştır. Çöktürülen hemiselülozlar 14000 rpm'de 5 dakika santrifüjlenmiş, sırasıyla etanol ve asetonla yıkandıktan sonra $105 \pm 2{ }^{\circ} \mathrm{C}$ 'de kurutulmuştur (Fang ve ark., 1999).

Dill ve ark. (1984)'e ait yöntem modifiye edildikten sonra kullanılarak ılgın örneği monosakkaritlerinin izolasyonu ve klason lignini tayini gerçekleştirilmiştir. Ekstrakttan arındırılmış $1 \mathrm{~g}$ tam kuru maddeye denk gelecek şekilde tartılan örneğe $20 \mathrm{ml} \% 72$ 'lik $\mathrm{H}_{2} \mathrm{SO}_{4}$ ilave edilmiş ve $30{ }^{\circ} \mathrm{C}$ 'de 2 saat süreyle hidroliz işlemi gerçekleştirilmiş, devamında 360 ml'ye saf su ile tamamlanarak otoklavda $120{ }^{\circ} \mathrm{C}$ 'de 30 dakika boyunca bekletilmiştir. Süzme işleminden sonra kalıntı olarak elde edilen klason lignini $105 \pm 2{ }^{\circ} \mathrm{C}$ 'de kurutulmuş ve miktarı ekstrakttan arındırılmış tam kuru materyal yüzdesi olarak belirlenmiştir. Ilgın monosakkaritlerini içeren asit hidrolizatı ise HPLC ile karbonhidrat analizinde kullanılmıştır (Yaşar ve ark., 2010). Çöktürülerek elde edilen hemiselüloz örneğinin analizinde aynı işlemlerden yararlanılmıştır. Asit hidrolizinden sonra hemiselüloz örneğinde kalıntı lignin miktarı tespit edilmiş ve hidrolizat içerisinde toplanan hemiselüloz yapıtaşı birimlerinin tespiti HPLC analizi ile gerçekleştirilmiştir. 
Toplam monosakkaritleri ve hemiselüloz yapıtaşlarını içeren asit hidrolizatlarının $\mathrm{pH}$ derecesi 7 oluncaya kadar baryum hidroksit ilave edilmiştir. HPLC analizleri SHIMADZU sistem cihaz ve bu cihaza bağlanmış olan Refractive Index (RI) dedektör kullanılarak gerçekleştirilmiştir. Enjeksiyonda $20 \mu \mathrm{L}$ hacim kullanılmıştır. $\mathrm{CH}_{3} \mathrm{CN}: \mathrm{H}_{2} \mathrm{O}(75 / 25$, v/v) mobil fazı oluşturmuş ve akış hızı dakikada $0,8 \mathrm{~mL}$ olacak şekilde uygulanmıştır. Monosakkaritlerin kromatografik ayrılmasında Luna $\mathrm{NH}_{2}$ kolonu (250x4.6 mm; id $\left.5 \mu \mathrm{m}\right)$ kullanılmış ve işlem $20{ }^{\circ} \mathrm{C}$ 'de gerçekleştirilmiştir (Yaşar ve ark., 2010).

Esterleme için tartılan $0.3 \mathrm{~g}$ hemiselüloz üzerine $15 \mathrm{~mL}$ saf su ilave edilerek $80^{\circ} \mathrm{C}$ 'de karıştırımış, $15 \mathrm{~mL} \mathrm{~N}, \mathrm{~N}$ dimetilformamid (DMF) eklendikten sonra karıştırma işlemine yaklaşık 5 dakika daha devam edilmiştir. Oluşan jel yapıdan suyu uzaklaştırmak için $50{ }^{\circ} \mathrm{C}$ 'de evaporasyon uygulanmıştır. Hemiselüloz açil klorür molar oranı 1:2 olacak şekildeki hazırlanmış oktanoil, dekanoil ve lauroil klorürün her birine $0.075 \mathrm{~g} \mathrm{LiCl}, 0.05 \mathrm{~g}$ 4dimetilaminopiridin (DMAP), $115 \mu \mathrm{L}$ trietilamin (TEA) ve 7.5 mL DMF eklenmiştir. $70-75^{\circ} \mathrm{C}$ 'de karışmakta olan sudan arındırılmış jel yapıya, hazırlanmış açil klorür çözeltileri farklı düzeneklerde 10 dakika içerisinde yavaş yavaş ilave edilmiş ve elde edilen 3 ayrı solüsyon 20 dakika karışmaya bırakılmıştır. Devamında karışımlar oda sıcaklığında soğutulduktan sonra üzerlerine $\% 95$ 'lik $60 \mathrm{~mL}$ etanol yavaş yavaş eklenmiştir. Süzme işleminden sonra elde edilen katı kısımlar (esterlenmiş hemiselülozlar) etanol ve aseton ile yıkanmış ve öncelikle 24 saat boyunca oda sıcaklığında bırakılmış, devamında 24 saat $55^{\circ} \mathrm{C}$ 'de etüvde kurutulmuştur (Fang ve ark., 1999).

Hemiselüloz örneği ve esterlerinin FTIR analizleri için Schimadzu IR Prestige-21 FTIR spektrometresi ve TGA analizleri için Perkin Elmer SII Diamond model termal analiz cihazı kullanılmıştır. $10 \mathrm{mg}$ tartılan örneklerin her birinin $1000 \mathrm{mg} \mathrm{KBr}$ ile preslenmesiyle üretilen peletlerin FTIR spekrumları 4000 ile $400 \mathrm{~cm}^{-1}$ dalga sayısı aralığında oda sıcaklığında elde edilmiştir. Örneklerin TGA analizleri, dakikada $10^{\circ} \mathrm{C}$ ısıtma hızında 25 ile $600^{\circ} \mathrm{C}$ aralığında azot ortamında gerçekleştirilmiştir.
DS tespiti için Leco CHNS-932 cihazı kullanılarak örneklerde belirlenen yüzde karbon değerlerinden faydalanılmıştır. Yüzde verim değerlerinin hesaplanmasında DS değerleri kullanılmıştır.

\section{BULGULAR VE TARTIŞMA}

Ilgın örneğine ait ana bileşenlerin tanımlanmasına yönelik analizler sonucu ekstraktif madde miktarı \%2.82, lignin miktarı $\% 20.49$, holoselüloz miktarı $\% 76.83$ ve $\alpha$ selüloz miktarı \%45.12 olarak tespit edilmiştir.

Ekstrakttan arındırılmış ılgın örneğine uygulanan asit hidrolizi sonucu elde edilen monosakkarit birimlerinin miktarları HPLC ile saptanmıştır. Ilgın örneğinde Glukoz, galaktoz, ksiloz, ramnoz, arabinoz ve mannoz miktarları sırasıyla \%44.38, \%0.94, \%23.98, \%0.58, $\% 0.97$ ve $\% 1.87$ şeklinde elde edilmiştir.

Ilgından izole edilen hemiselüloz örneği içerisinde \%3.92 oranında kalıntı lignin tespit edilmiştir. HPLC analizi sonucu hemiselüloz örneğinde glukoz \%2.03, galaktoz \%3.57, ksiloz \%85.68, ramnoz \%1.04, arabinoz \%3.24 ve mannoz \%4.44 olarak belirlenmiştir.

Hemiselüloz örneğinin oktanoil, dekanoil ve lauroil klorür ile türevlendirilmesi işleminde reaksiyon gerçekleşmediği takdirde C miktarı \%45.46 olacağından DS değeri 0 olarak elde edilecektir. Hemiselüloz örneğinin tamamının oktanoil, dekanoil ve lauroil klorür ile türevlenmesi durumunda ise $\mathrm{C}$ miktarları sırasıyla \%65.60, $\% 68.15$ ve \%70.12'ye denk geleceğinden ulaşılacak DS değeri 2 olacaktır. Yapılan elementer analiz sonucu oktanoil, dekanoil ve lauroil klorür ile türevlendirilmiş ılgın örneği hemiselülozlarında C miktarları sırasıyla $\% 52.31$, \%54.65 ve \%54.71 şeklinde saptanmıştır. \%C değerlerinden hesaplanan DS değerleri ise oktanoil, dekanoil ve lauroil klorür ile türevlendirilmiş örneklerde sırasıyla $0.68,0.81$ ve 0.75 şeklindedir (Tablo 1).

Tablo 1. Esterlenmiş ılgın örneği hemiselülozlarının DS değerleri

\begin{tabular}{lccccc}
\hline $\begin{array}{c}\text { Hemiselüloz ester- } \\
\text { leri }\end{array}$ & Molar oran* & $\begin{array}{c}\text { DS=0 için } \\
\text { teorik \%C } \\
\text { miktarı }\end{array}$ & $\begin{array}{c}\text { DS=2 için teo- } \\
\text { rik \%C miktarı }\end{array}$ & \%C & DS \\
\hline $\begin{array}{l}\text { Oktanoil klorür ile } \\
\text { türevlenmiş örnek }\end{array}$ & $1: 2$ & 45.46 & 65.60 & 52.31 & 0.68 \\
$\begin{array}{l}\text { Dekanoil klorür ile } \\
\text { türevlenmiş örnek } \\
\text { Lauroil klorür ile } \\
\text { türevlenmiş örnek }\end{array}$ & $1: 2$ & 45.46 & 68.15 & 54.65 & 0.81 \\
\hline
\end{tabular}

*:Hemiselüloz mol değeri/Oktanoil, dekanoil ve lauroil klorür mol değeri 
Hemiselüloz örneğinin oktanoil, dekanoil ve lauroil klorür ile türevlendirilmesi sonucu elde edilen örneklerin DS değerlerinden hesaplanan yüzde verim değerleri Tablo 2'de verilmiştir. Ilgın örneği hemiselülozlarının DS değeri 0 iken yani esterlemenin gerçekleşmediği durumda oktanoil, dekanoil ve lauroil klorür ile türevlendirmede yüzde verim değerleri sırasıyla 34.4, 29.9 ve 26.6 şeklindedir. Oysa oktanoil, dekanoil ve lauroil klorür ile hemiselülozların tamamının türevlendiği durumda DS değeri 2 olacağından yüzde verim 100 düzeyinde elde edilecektir. Çalışmamızda elde edilen ılgın örneği hemiselüloz türevlerinin DS değerlerinden hesaplanan yüzde verim değerleri oktanoil, dekanoil ve lauroil klorür ile türevlendirilmiş örneklerde sırasıyla $56.68,58.23$ ve 54.13 şeklinde belirlenmiştir.

Tablo 2. Esterlenmiş ılgın örneği hemiselülozlarının yüzde verimi

\begin{tabular}{lcccc}
\hline Hemiselüloz esterleri & Molar oran* & $\begin{array}{c}\text { Sıcaklık } \\
\left({ }^{\circ} \mathbf{C}\right)\end{array}$ & $\begin{array}{c}\text { Süre (da- } \\
\text { kika) }\end{array}$ & Verim (\%) \\
\hline $\begin{array}{l}\text { Oktanoil klorür ile } \\
\text { türevlenmiş örnek }\end{array}$ & $1: 2$ & 75 & 30 & 56.68 \\
$\begin{array}{l}\text { Dekanoil klorür ile } \\
\text { türevlenmiş örnek }\end{array}$ & $1: 2$ & 75 & 30 & 58.23 \\
$\begin{array}{l}\text { Lauroil klorür ile } \\
\text { türevlenmiş örnek }\end{array}$ & $1: 2$ & 75 & 30 & 54.13 \\
\hline
\end{tabular}

*:Hemiselüloz mol değeri/Oktanoil, dekanoil ve lauroil klorür mol değeri

Çalışmada elde edilen hemiselüloz esterlerine ait DS ve yüzde verim değerleri, literatürde rapor edilen (Fang ve ark., 1999; Sun ve ark., 1999, 2000; Ren ve ark., 2008; Xu ve ark., 2008; Tanrıverdi, 2011) farklı bitkisel kaynaklardan izole edilmiş hemiselülozların 1:2 molar oranda oktanoil, dekanoil ve lauroil klorür ile türevlendirilmesiyle üretilen örneklerde belirlenen DS ve yüzde verim değerleri ile benzerlik gösterdiği görülmüştür.

Ilgın örneği hemiselüzlarına ait FTIR spektrumu Şekil 1 'de verilmiştir. $3410 \mathrm{~cm}^{-1}$ 'deki band hemiselüloz içersindeki $-\mathrm{OH}$ gruplarını temsil etmektedir. $2922 \mathrm{~cm}^{-1}$ deki band metil metilen $\mathrm{C}-\mathrm{H}$ gerilmesini göstermektedir. $1666 \mathrm{~cm}^{-1}$ 'deki band numunede absorbe olmuş sudan kaynaklanmaktadır. 1473 ile $1170 \mathrm{~cm}^{-1}$ arasındaki alan $\mathrm{C}-\mathrm{H}$ ve $\mathrm{C}-\mathrm{O}$ bağlarının gerilme frekanslarına atfedilmiştir. $1048 \mathrm{~cm}^{-1}$ 'de görülen band glukozidik bağ içersindeki C-O gerilmesi ile ilgilidir. $900 \mathrm{~cm}^{-1}$ 'deki band şeker birimleri arasındaki $\beta$-glukozidik bağları temsil etmekte- dir (Sun ve ark., 2004). Hemiselüloz türevlerine ait spektrumlarda görülen $1742 \mathrm{~cm}^{-1}$ 'deki band oluşan estere ait karbonil grubu ile ilgilidir. 2922 ve $2854 \mathrm{~cm}^{-}$ ${ }^{1}$ 'deki bandlar simetrik ve asimetrik $\mathrm{C}-\mathrm{H}$ gerilmesine aittir (Fang ve ark., 1999; Sun ve ark., 1999, 2000; Xu ve ark., 2008; Ren ve ark., 2008). Oktanoil, dekanoil ve lauroil klorür ile türevlendirilmiş hemiselüloz örneklerinin FTIR spektrumlarındaki $1742 \mathrm{~cm}^{-1}$ deki meydana gelen band, $2922 \mathrm{~cm}^{-1}$ deki bandın absorbans değerlerindeki yükseliş, $2854 \mathrm{~cm}^{-1}$ 'deki bandın belirginleşmesi ve $3410 \mathrm{~cm}^{-1}$ deki -OH bandına ait absorbans değerlerindeki önemli düzeylerdeki düşüş esterleme işleminin gerçekleştiğini göstermiştir (Şekil 1). Çalışmaya ait FTIR analizi sonuçları literatür (Fang ve ark., 1999; Sun ve ark., 1999, 2000; Xu ve ark., 2008; Ren ve ark., 2008) verileriyle örtüşmektedir. 


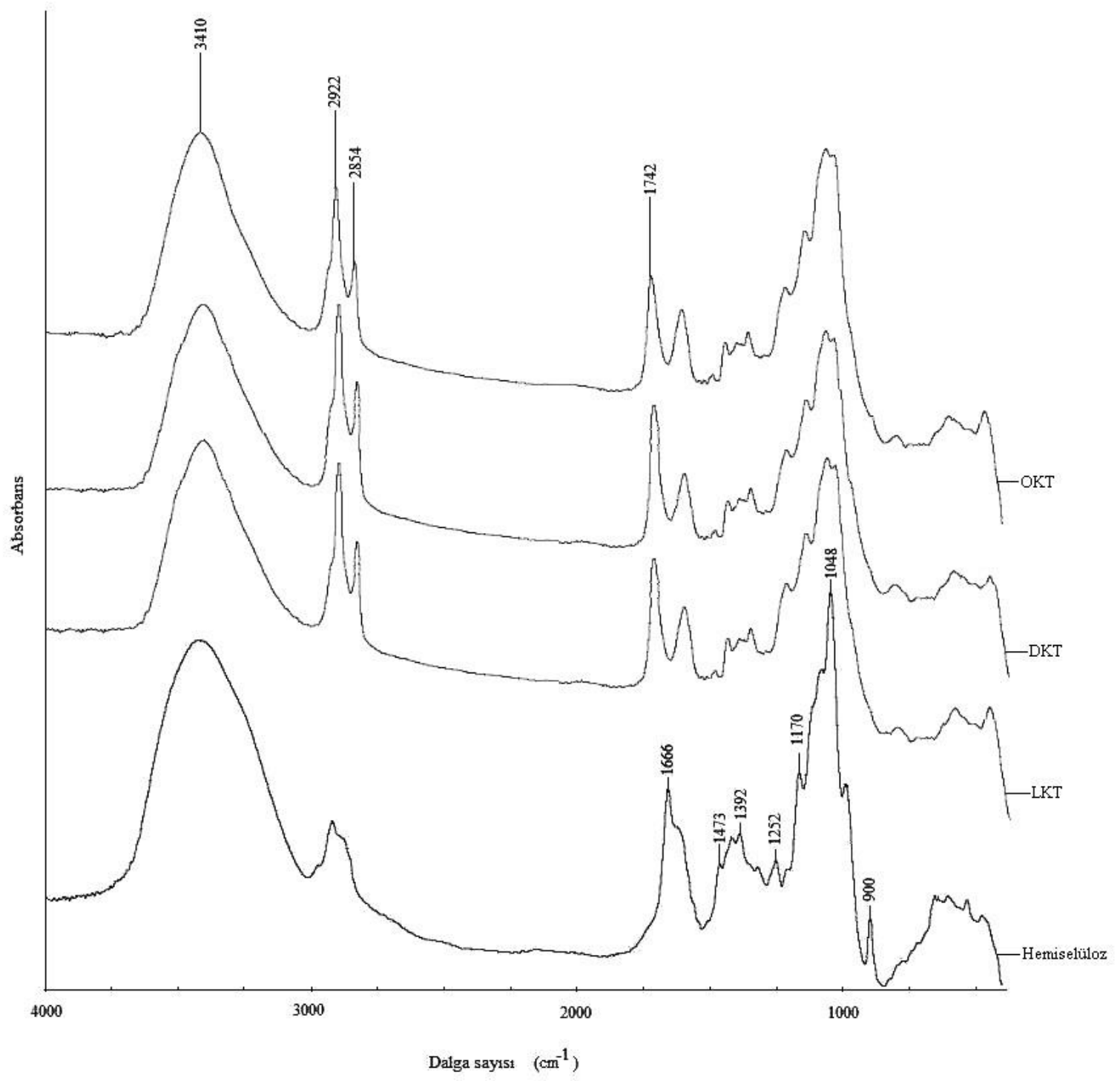

Şekil 1. Hemiselüloz ve türevlenmiş örneklerin FTIR spektrumları (OKT: Oktanoil klorür ile türevlenmiş örnek, DKT: Dekanoil klorür ile türevlenmiş örnek, LKT: Lauroil klorür ile türevlenmiş örnek)

Ilgın örneği hemiselülozları ile oktanoil, dekanoil ve lauroil klorür ile türevlenmiş hemiselüloz örneklerine ait
TGA ve DTG (diferansiyal termogravimetrik analiz) termogramları Şekil 2 ve 3'te gösterilmiştir. 


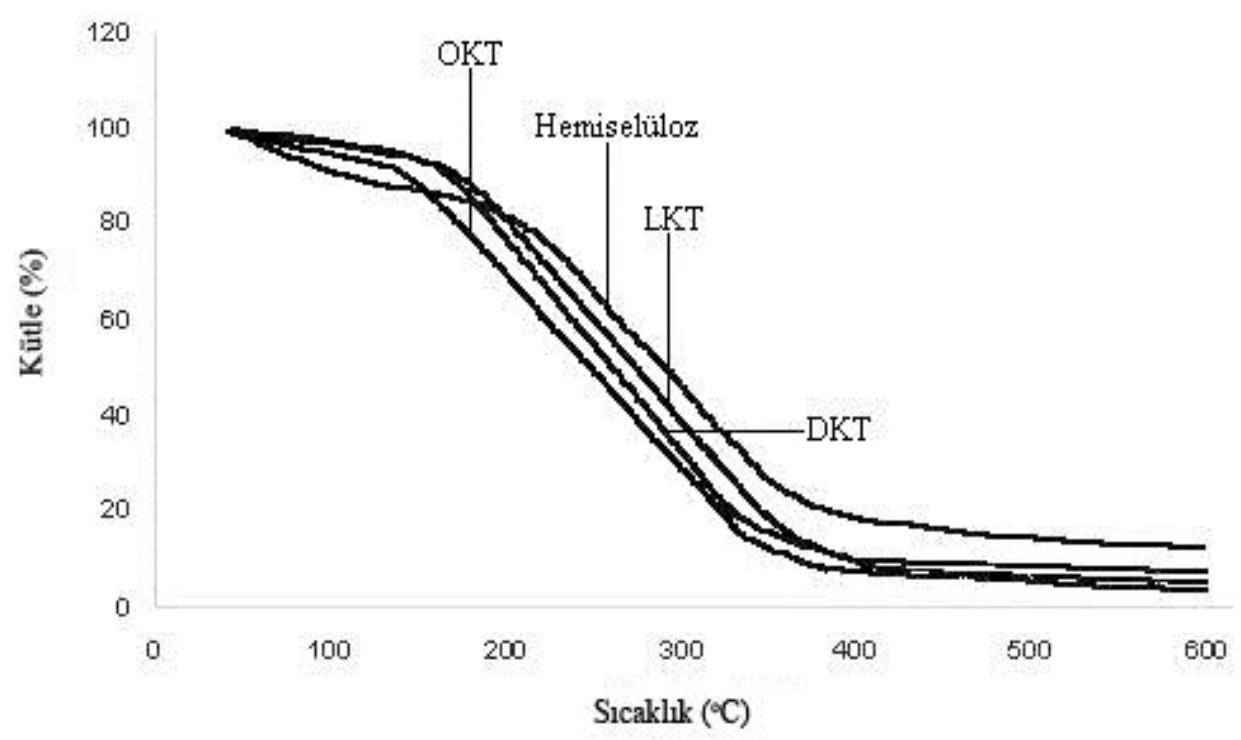

Şekil 2. Hemiselüloz ve türevlenmiş örneklerin TGA termogramları (OKT: Oktanoil klorür ile türevlenmiş örnek, DKT: Dekanoil klorür ile türevlenmiş örnek, LKT: Lauroil klorür ile türevlenmiş örnek)

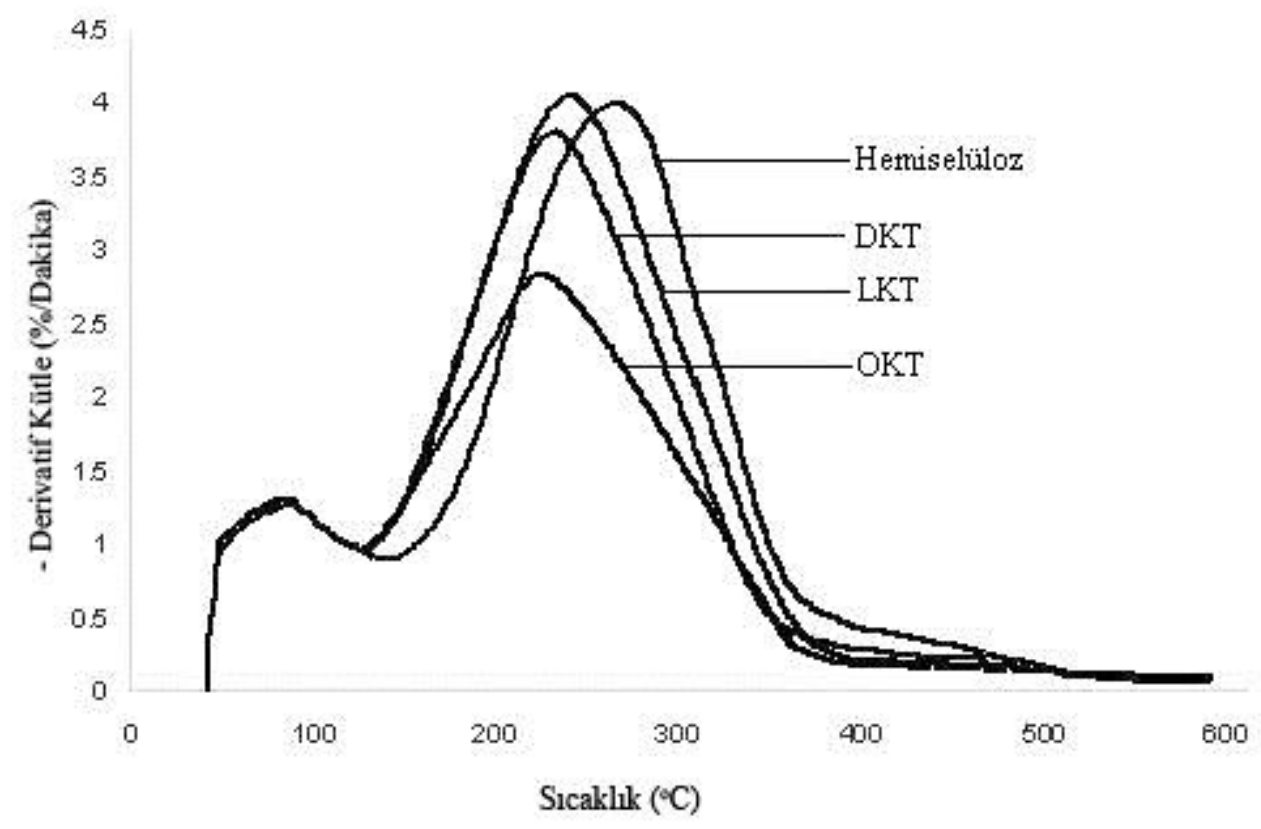

Şekil 3. Hemiselüloz ve türevlenmiş örneklerin DTG termogramları (OKT: Oktanoil klorür ile türevlenmiş örnek, DKT: Dekanoil klorür ile türevlenmiş örnek, LKT: Lauroil klorür ile türevlenmiş örnek)

Hemiselüloz ve türevlendirilmiş hemiselüloz örneklerinde esas termal bozunma $120{ }^{\circ} \mathrm{C}$ 'den itibaren başlamış ve hemiselüloz örneğinde $520^{\circ} \mathrm{C}$, oktanoil klorür ile türevlendirilmiş örnekte $398{ }^{\circ} \mathrm{C}$, dekanoil klorür ile türevlendirilmiş örnekte $401{ }^{\circ} \mathrm{C}$ ve lauroil klorür ile türevlendirilmiş örnekte $404{ }^{\circ} \mathrm{C}^{\prime} \mathrm{ye}$ kadar devam etmiştir. Maksimum bozunma sıcaklığının hemiselüloz örneğine göre oktanoil klorür ile türevlendirilmiş örnekte $43{ }^{\circ} \mathrm{C}$, dekanoil klorür ile türevlendirilmiş örnekte $38{ }^{\circ} \mathrm{C}$ ve lauroil klorür ile türevlendirilmiş örnekte $30^{\circ} \mathrm{C}$ düştüğü tespit edilmiştir. Maksimum bozunma sıcaklıklarında görülen düşüşler, türevlendirilmiş örneklerin termal dayanıklılığının hemiselüloz örneğine göre daha $a z$ olduğunu ortaya koymuştur. 
Çalışmada, TGA ve DTG analizleri sonucu elde edilen türevlendirilmiş örneklere ait bulguların literatürdeki (Xu ve ark., 2008, Sun ve ark., 2004; Yuan ve ark., 2011) düşük DS ve yüzde verim değerlerine sahip hemiselüloz esterlerine ait verilerle karşılaştırılabilir düzeyde olduğu görülmüştür.

\section{SONUÇLAR}

Çalışmada, orman endüstrisinin bazı üretim alanlarında hammadde olarak kullanılabilecek ılgından elde edilen hemiselülozların \%85.68'inin ksiloz birimlerinden oluştuğu görülmüştür. Hemiselüloz örnekleri oktanoil, dekanoil ve lauroil klorür ile türevlendirilmiş ve üretilen ester yapıların düşük sübstitüsyon derecesine $(0.68-0.81)$ ve verim yüzdesine (\%54.13-58.23) sahip olduğu belirlenmiştir. Hemiselüloz esterlerinin FTIR spektrumlarındaki özellikle $1742 \mathrm{~cm}^{-1}$ 'deki ester pikinin görülmesi, 2854 ve $2922 \mathrm{~cm}^{-1}$ deki metil metilen grubuna ait pik değerlerinin belirgin bir şekilde artışı, $3410 \mathrm{~cm}^{-1}$ 'deki pik değerindeki düşüş esterlenmenin gerçekleştiğini ortaya koymuştur. Hemiselüloz örneğinin termal dayanıklılığının ester yapılardan daha yüksek olduğu TGA analizleri ile belirlenmiştir.

\section{KAYNAKLAR}

Cooper, P., Balantinecz, J. (1999). Agricultural waste materials for composites: A Canadian reality. Centre for Management Technology Global Panel Based Conference, Nikko Hotel, Kuala Lumpur, 18-19 October.

Dill, I., Salnikow, J., Kraepelin, G. (1984). HydroxyprolineRich Protein Material in Wood And Lignin of Fagus Sylvatica. Applied and Environmental Microbiology. 48(6), 1259-1261.

Fang, J.M., Sun, R., Fowler, P., Tomkinson, J., Hill, C.A.S. (1999). Esterification of Wheat Straw Hemicelluloses in the N,N-Dimethylformamide/Lithium Chloride Homogeneous System. Journal of Applied Polymer Science, 74, 2301-2311.

MEB-MEGEP. (2007). Bahçecilik, Süs Ağaççıkları, Ankara.
Önal, E. (2007). Farklı Biyokütlelerin ve Bunların Sentetik Polimerlerle Birlikte Pirolizi, Elde Edilen Ürün Özelliklerinin Belirlenmesi. Anadolu Üniversitesi, Fen Bilimleri Enstitüsü, Doktora Tezi, Eskişehir.

Ren, J., Xu, F., Sun, R.C., Peng, B., Sun, J. (2008). Studies of the Lauroylation of Wheat Straw Hemicelluloses under Heating. Journal of Agricultural and Food Chemistry, 56, 1251-1258.

Sun, R.C., Fang, J.M., Tomkinson, J., Hill, C.A.S. (1999). Esterification of Hemicelluloses from Poplar Chips in Homogenous Solution of N,N-Dimethylformamide/Lithium Chloride. Journal Of Wood Chemistry and Technology, 19(4), 287-306.

Sun, R.C., Fang, J.M., Tomkinson, J. (2000). Characterization and Esterification of Hemicelluloses from Rye Straw. Journal Agricultural Food Chemistry, 48, 1247-1252.

Sun, R.C., Fang, J.M., Tomkinson, J., Liu, J.C., Geng, Z.C. (2001). Fractional Isolation, Physico-chemical Characterization and Homogeneous Esterification of Hemicelluloses from Fast-Growing Poplar Wood. Carbohydrate Polymers, 44, 29-39.

Sun, X.F., Sun, R.C., Sun, J.X. (2004). Oleoylation of Sugarcane Bagasse Hemicelluloses using N-Bromosuccinimide as a Catalyst. Journal of The Science of Food and Agriculture, $84,800-810$.

Tanrıverdi, H. (2011). Haşhaş Sapı (Papaver somniferum L.) Hemiselülozlarının N,N-Dimetilformamit/Lityum Klorür Homojen Sisteminde Esterifikasyonu. Süleyman Demirel Üniversitesi, Fen Bilimleri Enstitüsü, Doktora Tezi, Isparta.

Wise, E.L., Karl, H.L. (1962). Celluloese and Hemicellulose in Pulp and Paper Science and Technology. Libby, C.E. (Ed.), Vol:1, Mc Graw Hill Book Co., New York.

Xu, F., Jiang, J.X., Sun, R.C., She, D., Peng, B., Sun, J.X., Kennedy, J.F. (2008). Rapid Esterification of Wheat Straw Hemicelluloses Induced by Microwave Irradiation. Carbohydrate Polymers, 73 (4), 612-620.

Yaşar, S., Güller, B., Baydar, H. (2010). Susam (Sesamum indicum L.), Pamuk (Gossypium hirsitum L.) ve Haşhaş (Papaver somniferum L.) Saplarında Karbonhidrat, Lignin Miktarları ve Bazı Lif Özellikleri Üzerine Araştırmalar. SDÜ Orman Fakültesi Dergisi 1, 56-66.

Yuan T., Sun, S., Xu, F., Sun, R. (2011). Homogeneous Butyrylation and Lauroylation of Poplar Wood in the lonic Liquid 1-Butyl-3-Methylimidazolium Chloride. Bioresource Technology, 102, 4590-4593. 